15 Greer and Orleans, op. cit., p. 836.

16 Greer, op. cit., p. 55.

17 Ibid., p. 42.

18 Ibid., p. 41.

19 Ibid., p. 45.

20 Ibid., p. 51.

21 These four questions are suggested by Leo F. Van Hoey, op. cit., as the key questions of process analysis.

22 The arrows in this chart refer to recruitment.

\section{EDUCATION AND THE CHANGING SOCIETY}

\author{
IN SIERRA LEONE \\ Gerald O. Windham \\ Southern Illinois University \\ Carbondale, Illinois
}

Introduction

Ethnologies have described fairly adequately the cultural system of the major tribal societies in Africa. The tribal groups in Sierra Leone have received their share of attention in ethnographies of the Mende, Kono, Limba, and Sherbro and in less comprehensive studies of the Temne and other tribal groups. ${ }^{1}$ In addition, the non-tribal Creole society in the Western Area has been of interest to social scientists and laymen alike since the colony for freed slaves was established by Europeans in the early 1700 's. ${ }^{2}$

Traditionally, Sierra Leone consisted of approximately 15 tribal groups. Each had its own language and culture. There were major differences among the societies with regard to specific customs and practices. However, because of a similar physical environment the societies were amazingly similar with respect to the economic, political and family organization. The following patterns were more or less uniform among the tribal societies.

The economy was based on a subsistence agriculture consisting chiefly of upland rice and, where suitable, swamp rice, cassava, groundnuts and an assortment of tropical vegetables. Goats, sheep and chickens were the only livestock, and these were used more for ceremonial purposes than for the protein that they could provide in the soup for the rice. There was no draft power and an abundance of child and female labor was necessary for the accumulation of "wealth". A pagan god was at the center of the religious system and there was a strong belief in spirits, magic, witchcraft and sorcery. Most social occasions had religious significance such as burials, the planting of rice, making sacrifices to the ancestors and so on. Each tribal area was divided into a number of political units known as Chiefdoms. A ruling clan provided the Paramount Chief who ruled his subjects autono- 
mously. He settled land disputes, punished infractions of the mores in his court and so on.

The education of youth was accomplished informally for such things as farming, weaving and hunting. The most important things concerning relationships between the sexes and ritual were taught formally through the secret societies. There were a number of secret societies for males, and one progressed through them somewhat like a person earns degrees in the Masonic order in the United States. The access to a secret society was passed from a father to his sons. The higher ranked societies, those having to do with medicine, religion, and magic were not open to certain families. However, every male was initiated into the first society - usually Poro. Although the function and ritual of the first society varied among tribes, its functions included, among other things, circumcision and preparation for the assumption of adult roles. 3 There was only one secret society for females - the Bondo. The primary function of Bondo was to prepare females for marriage. The rites of circumcision were performed and initiates were instructed in motherhood.

Polygyny was the predominant form of marriage. Males wanted as many wives as they could acquire. There was a compulsion to get as many children as God wanted to give you and it was said that the married woman was most beautiful when pregnant. At the same time however, the marriage system had a birth control system built in. Intercourse was not permitted during pregnancy and while the mother nursed her child - usually for three years.

Marriages were arranged by parents for their sons. Parents paid the brideprice and sometimes the costs of rearing the future bride. However, "big men" might acquire wives for themselves without the help of their parents. Marriages were sometimes contracted at birth when a "big man" paid the baby girl's parents a price for their daughter whom he would marry when she was initiated into Bondo. In this case the man would make regular contributions to the girl's parents, pay for initiation into Bondo and so on. Virginity was revered. On the wedding night the bride's mother bathed the bride and dressed the bed with a piece of white satin. In the morning the satin was retrieved. If it had blood on it, the bride's family had a big celebration. In some tribes, the satin was used as a headpiece for the bride during the celebration Divorce was uncommon. If the wife left her husband, her family was obligated to return the brideprice. Wives usually went to their mother's to have children and frequently left the baby for its grandmother to keep until it could work in the fields. In spite of this system, however the child belonged to its father and not its mother.

The traditional societies have changed considerably since the ethnographies were conducted. One cannot point to any single factor which has undermined the traditional societies. Hopkins asserts that the spread of Christianity was perhaps the most important agent of change in all of sub-Saharan Africa. 4 Any attempt to explain the "Westernization" of Africa must include the work of the Christian missionaries, of course. However, the concomitants of Christianity were probably more appealing to the African than the philosophy of Christian brotherhood. In a study of Educational Development in Sierra Leone, I have shown that the educational system exists for the most part as a result of the efforts of Christian Missionaries. 5 One can argue that conversion to Christianity created a desire for formal education, the whiteman's juju, and a Western outlook in general. ${ }^{6}$ However, it is just as plausible to argue that the mission schools and hospitals provided the incentive for Christianization. I have found no study of the degree to which converts to Christianity in Sierra Leone embrace the tenets of Christianity. It is fairly obvious, however, that many converts are more receptive to education for their children and to modern medicine than they are to giving up such things as polygyny, ancestor worship, and the practice of witcheraft. 7

Muir contends that economic development through industrialization is one of the major incentives to change from traditionalism to Western outlook. He presents data from an industrial training program in Sierra Leone which shows that young male adults who were socialized in a tribal environment acquired a respect for a somewhat less tribalistic way of life as they acquired aptitudes necessary for work with complicated industrial machines. 8

Elsewhere in West Africa, Omari has shown that formal educationa attainment is a powerful force in the estrangement of youth from the traditional society in Ghana. 9 His work has been concerned with the role of education in the emancipation of youth from traditionalism in family relationships. He shows the implication of the changes to the wider cultural system, however, and leaves the inquisitive reader with the impression that educational attainment beyond the primary level is a sufficient condition to the transformation of the traditional Ghanian to a prototype of the "modern Western man."10

It is obvious that any attempt to explain change in Africa must make provision for a host of independent variables which may be viewed a incentives to change. Among others, these include: (1) institutiona changes which emanated from the outside, such as political change introduced through colonialism, and educational and medical advances which were concomitants of Christianization; (2) economic change through industrialization, commerce, agriculture and mining; and (3) change accelerating personnel and activities which have recently been provided by the various foreign governments, the United Nations, and so on. There has been no longitudinal study of change in Sierra Leone. However, it is possible to gauge change by comparing the findings from 
contemporary studies with the ethnographies and other studies previously cited.

\section{The Purpose and Method}

The purpose of this paper is to examine the attitudes of secondary school students in Sierra Leone toward several aspects of family life; to place these attitudes within the perspective of a society in transition; and to draw implications from these data to the development of the country in general. The data were collected from a representative sample of Form III and Form V students in two schools in the Southern Province. A roster of students enrolled in the two levels in each school was provided by the principals, and a table of random numbers was used to select one student from each three on the roster. One hundred and twenty students were selected for the sample and 118 were interviewed. One school was a boys' school and the other had a small percentage of girls enrolled. Hence, only eight of the students interviewed were females. These were subsequently dropped from the analysis, leaving a total sample of 110 . A group interview was used. The students assembled in groups of twenty or less. The study was explained and instructions for filling in the pre-coded questions were given. Advanced students from Njala University College read the questions to the interviewees, and, when necessary, gave an adequate explanation of the questions. The interviewees were not permitted to discuss the questions among themselves and were spaced in such a way that answers could not be compared. Personal interviews were conducted with a sub-sample of students in an effort to clarify the data and to determine if the students had misunderstood the questions or the intent of the study. Cooperation was good and the students appeared to enjoy this new experience.

The study was designed to ascertain the educational and occupational aspirations of the students and to isolate factors in their background which were related to differential aspirations and expectations. 11 The data revealed that 90 percent of the students wanted to enter high status professions such as medicine and the law or to become politicians. Practically, all of those who wanted to enter professions fully expected to do so. They were aware of the many conditions which would have to be overcome in order to attain their goals, but felt that the G.C.E. examination was the only real obstacle in their path. 12 This seems unrealistic when viewed from an American perspective, but may be realistic within the local context inasmuch as the present practice of the government is to provide full scholarships to those with five passes on the G.C.E., either in local colleges or through scholarships provided by foreign governments. In view of these findings, it was decided to make a descriptive presentation of attitudes on family relationships and practices. These data have theoretical significance inasmuch as they present insights into the present thinking of the future leaders of the country. These attitudes and opinions can be compared with the previously documented attitudes of adults living in the traditional societies and their implications for change shown.

\section{The Sample and Schools Studied}

The schools represent polar types insofar as their history and present emphasis are concerned. School A is co-educational and is supported by the Evangelical United Brethren Mission in Sierra Leone. It is located in a town of approximately 1,500 and is situated on the main highway in the country. The town serves as a trading center where peasant farmers bring their small yields of ginger, palm kernels and rice to exchange for staples such as sugar, dried fish, palm oil and cloth. There is an E.U.B. mission hospital and eye clinic in the town. The eye clinic is one of the most successful in West Africa and performs surgery, fits glasses and so on for persons from other West African countries as well as from all over Sierra Leone. The population is predominately Christian and the largest E.U.B. congregation in the world is located there. A nearby college and a government operated palm and citrus plantation provide work for a large number of individuals.

School B is the now locally renowned government secondary school at Bo. This school was established in the early 1900's to provide education for the sons of Paramount Chiefs and to counteract the "gay" and "corrupting" influences of mission education. 13 Originally students were required to return to their villages after graduation and were not permitted to sit the civil service examination. The school has since changed its approach, and recently has provided a preponderance of the Members of Parliament, civil servants and other leaders of the country. Bo town has a population of approximately 30,000 . It is the capital of the Southern Province and was the capital of the Protectorate before the Crown Colony and Protectorate were united as an independent republic in 1961.14 It is therefore an administrative and commercial center with some light industry. The population is mixed Christian, Muslim and pagan, and most tribes in the country are represented.

Both schools have indigenous and expatriate teachers. As with all secondary schools in Sierra Leone, both schools are heavily oriented toward the British classical approach. However, the mission school was one of the first in Sierra Leone to offer vocational agriculture and domestic science (home economics), and its principal has advocated the inclusion of these subjects in the West African G.C.E.examination. 15 Both schools have dormitories for boarding students. There are no reliable statistics on the population of the country and it is not possible 
to compare the students with the general population. Table 1 shows, however, that both schools enroll disproportionately more students from the Mende tribe than are found in the general population -31 percent. 16 This is partly explained by the location of these schools in Mende country. However, the Mende quickly accepted Christianity, modern education and the other concomitants of Christianity. The Temne, Foullah, Limba, and Loko are Muslim for the most part. The Muslims have rejected Christian education and all it stands for. 17 There is little doubt that the students in both schools are from "middle" and "upper" class families as one dysfunction of the present educational system is that it makes it extremely hard for "lower" class children to attend secondary school.18 Also, the occupations and education of fathers suggest this. Both schools have a large percentage of students with farm backgrounds, considering the level of development in Sierra Leone agriculture.19 However, the status of the family is dependent upon members of the extended family rather than one's parents as such. An examination of the status of the extended family of these students would probably show that someone in the family is responsible for school fees, for securing a scholarship, and for other forms of support which are so important in a developing country.

TABLE 1

SELECTED CHARACTERISTICS OF THE SAMPLE BY SCHOOL

\begin{tabular}{lc}
\hline CHARACTERISTIC & SCHOOL \\
& Mission Govt. \\
& $\% \mathrm{~N}=42 \% \mathrm{~N}=68$
\end{tabular}

Where live

Dormitory

Parents

Guardian

Other

Tribe

$\begin{array}{lrr}\text { Mende } & 74 & 54 \\ \text { Temne } & 6 & 15 \\ \text { Foullah } & - & 10 \\ \text { Kono } & 4 & 4 \\ \text { Other } & 16 & 16\end{array}$

Religion

Muslim
Table 1 (cont'd)

\section{CHARACTERISTICS} SCHOOL Mission Govt. $\% \mathrm{~N}=42 \% \mathrm{~N}=68$

Source of scholarship

Government

Church

Commercial firm

No scholarship

Type of family

Polygynous

$57 \quad 78$

Monogamous

Marital status of parents

*Parents living together

Parents widowed, separated or divorced

Father's education

Did not attend school

Primary

Secondary

Post-secondary

Mother's education

Did not attend school

Primary

Secondary

Post-secondary

Father's occupation

\section{Farme}

Trader

**Government

***Civil Service

Professional

Other

Unemployed

This question presented some difficulty. The divorce rate in Sierra Leone is low. However, desertion is very common and premature death of a spouse is frequent. Polygynous marriages 


\section{THE DATA}

Family Practices

The data show the conflict which the students experience as they attempt to live the life of a student in a Western institution (the school), on the one hand and the traditional society on the other. About half, for example, favor arranged marriages. A large percentage of students who did not favor arranged marriages (62 percent), stated that their marriages would be arranged for them anyway. The remainder indicated that their parents would have to approve of the marriage; settle the pre-marital arrangements with the girl's parents, whether or not a brideprice was involved; and see that the marriage went well in the initial stage. In reality the only difference between this arrangement and the more institutionalized "business transaction" is that some degree of choice rests with the student and a degree of pre-marital romantic love is permitted.

The concept of romantic love was held by a majority of the students, and surprisingly was used by both those who favored arranged marriages and those who did not, to justify their position. The most frequently given reasons for not favoring arranged marriages were, "my parents will not know how to choose a girl that I can love and respect", and "they will choose a daughter-in-law for themselves rather than a wife for me". The most frequently given reason for favoring arranged marriages was that parents know more about love than their children and they can show more discretion in choosing a love partner. In the personal interview it was discovered that a large proportion of the students had actually participated in love relationships from the time of initiation into the secret society. Strangely enough, several of the boys

follow two patterns: (1) all wives live in a compound with the husband, or (2) wives are scattered among several villages. The second pattern is most often found among persons who engage in second pattern is most often found among persons who engage in occupations other than farming. In either case, when students living together, this meant the father had some schedule for sleeping with his mother if all or most of the wives lived in the compound. If the wives were scattered among the villages, it simply meant the husband slept with his wife when he visited the village in which she lived.

**Includes: Paramount or Sub-chief, Member of Parliament or one of the governmental ministries, District Commissioner, District Government Worker, such as Agricultural Officer, Welfare Officer and so on.

*** Clerks, Typists, Messengers, and so on. volunteered information that they had received information about sex and "loving" from their mothers. This information was not elicited. Therefore, its prevalence is not known. However, subsequent interviews with college students revealed that the mother is more likely to impart information on sex and "loving" than the father and that mothers are supposed to police pre-marital sex activity.

Eighty-nine percent of the students did not favor polygynous marriages. Only two students who came from monogamous families wanted to take more than one wife themselves. Ten of those from polygynous families wanted more than one wife. A profile of the "polygnists" revealed that they were from the more typical traditional backgrounds, and they fully expected to return to a tribalistic way of life after completion of their education. Surprisingly, eight were Christians and four were Muslims. The occupations of their fathers were: Chief, District Commissioner or other political position - six; peasant farmer - five; and trader - one. Six of the polygynists likewise expected to enter politics or become a Chief, one expected to become a carpenter, and five expected to become farmers. Those who expected to enter politics or become a Chief stated that they would have to take more than one wife to attain their vocational objective, and those who expected to become farmers said they would need extra wives and children in order to have laborers. Not surprising, two wanted 15 or more children, two wanted 12 and the remainder wanted from four to six. Ten of the polygynists said that after they married, their first obligation would be to their own mother or father or to members of the extended family other than their own wives and children.

The students were asked to provide reasons why they approved or did not approve of polygynous families. Nearly 90 percent of those who came from polygynous families and did not approve of polygyny themselves gave as their major criticism, "the lack of love and respect among family members", or "there is too much jealousy among wives", "there is always friction of some sort". Other criticisms were "your wives will always be 'loving' other men", and "you get too much responsibility when you have more than one wife". One Muslim said, "It's not the thing to do in a civilized society even if your religion does permit it". Those who had only experienced polygyny vicariously were less critical of it than others. Even among this group, however, the most frequently given criticisms were "jealousy", "lack of love and respect", and "too many women in polygynous marriages have lovers other than their husband". Only six students (four from the mission school and two from the government school), gave religious reasons for their disapproval of polygyny. Finally, two farsighted students said they wanted to eliminate polygyny in Sierra Leone so everyone could have one wife. They felt that this would result in a better society because it would eliminate the many cases in the native administration court 
involving wife damage; fathers would get to know their children; children would have a better chance of getting an education, and so on. 20

About half of the students said they wanted to limit the size of their families either through single marriages or the practice of birth control. A major departure from the traditional society is the changing attitude toward the role of wife from "field hand" or "money earners" in the market place through petty trade to that of mother and homemaker. Only about half of the students expect their wives to contribute to the support of the family through farming or economic activity. It is highly unlikely, however, that many of the students will actually practice the ideals of the Western culture which they now espouse. The practice whereby the wife engages in trade in order to support herself and her children seems to be rather common among "educated" and "uneducated" Sierra Leoneans alike. Apparently, this generation of "educated" Sierra Leoneans had retained this aspect of the indigenous culture, and they justify it on the basis of economic necessity.

Table 3 presents the responses of students to questions regarding the importance of selected characteristics in a marriage partner. These responses are not unlike what one would hypothesize for an American or British sample.21 The students place major emphasis on characteristics associated with the romantic love complex, such as a friendly personality, good looks, intelligence, good health, compatible religious beliefs, and so on. The list includes several characterisitics which have been hypothesized as being of major importance in Sierra Leone. These are: (1) those associated with nepotism (a rational and integral part of Sierra Leone society); (2) tribal identity; and (3) family obligations.

A significantly smaller population of students in the mission school than in the government school considered the job of the girl's father and that she know the right people (nepotism), as being important. Students in the mission school would not be as likely to object if the girl were obligated to her extended family (54 percent), as students in the government school (27 percent). In both cases, however, this is a surprisingly high percentage in view of the fact that males in the traditional societies have generally considered themselves only obligated to their own extended family. A surprisingly low proportion consider the girl's tribal identity as important - about one-fourth in the government school and about one-half in the mission school. Although its proportion may be exaggerated, tribalism appears to be a major problem to the emerging nations of Africa, and certainly it has been one of the major forces behind recent political and social developments in Sierra Leone. It is impossible to determine from the data how strong tribal feelings are among the students. Moreover, one cannot specify the maximum safe amount of tribal feelings for a country. However, it may be that tribalism is not as prevalent in Sierra Leone as some have
TABLE 2

ANTICIPATED FAMILY AND BY SCHOOL

PRACTICES SCHOOL

Mission Govt

$\% \mathrm{~N}=42 \% \mathrm{~N}=68$

Attitudes toward arranged marriages

Favor

Do not favor

Expect wife to work outside of home Yes

No

Number of wives desired

1

4 or more

87

11

2

Age want to get married

$$
\begin{aligned}
& 21-24 \\
& 25-29
\end{aligned}
$$

30 and over

Number of children desired

$$
\begin{aligned}
& 1-4 \\
& 5-9 \\
& 10-14 \\
& 15 \text { or more }
\end{aligned}
$$

Percent who say their first obligation after marriage to:

Their own wife and children

Their own mother or father

Their full brothers and sisters

Others

$\begin{array}{rr}35 & 43 \\ 56 & 57 \\ 6 & - \\ 3 & -\end{array}$


contended. If tribal feelings are in fact strong among the general population, it means that education will play a major role in the elimination of strong tribalistic feelings.

TABLE 3

IMPORTANCE OF SELECTED CHARACTERISTICS IN CHOOSING A PERSON TO MARRY BY SCHOOL

\begin{tabular}{|c|c|c|c|c|}
\hline \multirow[t]{3}{*}{ CHARACTERISTICS } & \multicolumn{4}{|c|}{ SCHOOL } \\
\hline & \multicolumn{2}{|c|}{$\begin{array}{l}\text { Mission } \\
\% N=42\end{array}$} & \multicolumn{2}{|c|}{$\begin{array}{c}\text { Government } \\
\% \mathrm{~N}=68\end{array}$} \\
\hline & $\begin{array}{l}\text { Very im- } \\
\text { portant } \\
\text { or im- } \\
\text { portant }\end{array}$ & $\begin{array}{l}\text { Not very } \\
\text { important } \\
\text { or not } \\
\text { important }\end{array}$ & $\begin{array}{l}\text { Very im- } \\
\text { portant } \\
\text { or im- } \\
\text { portant }\end{array}$ & $\begin{array}{l}\text { Not very } \\
\text { important } \\
\text { or not } \\
\text { important }\end{array}$ \\
\hline Intelligence & 94 & 6 & 100 & 0 \\
\hline *Secondary school education & 70 & 30 & 80 & 20 \\
\hline College education & 60 & 40 & 52 & 48 \\
\hline *Studied abroad & 70 & 30 & 80 & 20 \\
\hline *Tribal identity & 46 & 54 & 26 & 74 \\
\hline *Father's job & 10 & 90 & 26 & 74 \\
\hline *Knows the right people & 70 & 30 & 83 & 17 \\
\hline Wealthy parents & 30 & 70 & 38 & 62 \\
\hline Wants to make money & 82 & 18 & 78 & 22 \\
\hline Hard worker & 88 & 12 & 85 & 15 \\
\hline Healthy & 100 & 0 & 99 & 1 \\
\hline Religious beliefs & 80 & 20 & 72 & 28 \\
\hline *Good looking & 81 & 19 & 97 & 3 \\
\hline Friendly personality & 84 & 16 & 85 & 15 \\
\hline *Does not get angry easily & 70 & 30 & 81 & 19 \\
\hline *Likes children & 84 & 16 & 97 & 3 \\
\hline *Not obligated to her family & 46 & 54 & 73 & 27 \\
\hline
\end{tabular}

* Significant at .05 level of probability as shown by a test of difference between proportion.

TABLE 4

RESPONSE OF STUDENTS TO QUESTIONS REGARDING FAMILY ATTACHMENT BY SCHOOL

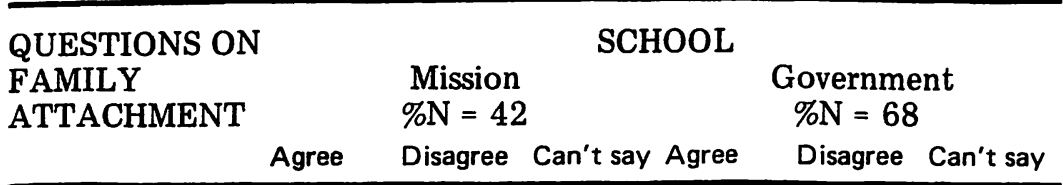

The most important

thing in life is to

help one's family

in time of need.

94

4

92

4

Nothing in life is

worth leaving one's

family.

59

17

24

53

26

I like to spend holidays

at home with $\mathrm{my}$

parents.

64

32

46

A person should stay

near his family even

if it means giving up

a good job.

4

88

8

4

84

Family Attachment

The hold which the extended family has on its members in Africa has been well documented. One writer has said that every man in Sierra Leone is a virtual milk cow. The minute he gets a few shillings ahead, a horde of relatives descend on him for school fees, brideprice, a doctor's fee to cover badly needed medical attention, a bushel of rice or a host of other pressing needs too numerous to mention.22 I have discussed this informally with a number of "educated" Africans who see it as one of the biggest dilemmas facing the society in general today. On the one hand, they see it as a heavy and undesirable financial burden. On the other, they must practice it for social reasons and admit that as long as a family member can "come to them" their obligations are clear.

It is extremely hard for a Western observer to untangle in a rational way the complicated relationships which obtain. Mothers frequently bear children and take them to their mother's to rear. Fathers sire sons and take them to their brother's who see to it that they get a rudimentary education. Monogamous fathers who are left with children 
because of the death of their wife leave them in missions and sometimes abandon them. Yet practically everyone is reluctant to take a child which is not somehow related to the extended family. Inevitably, fathers who have not seen their children since birth have a way of showing up when it is time to collect the brideprice or the child is old enough to make a rice farm 23 In spite of this, the child is obligated to his biological father, in addition to, or instead of its social father. This pattern is less prevalent among "educated" Sierra Leoneans, of course. However, the education of a family member probably acts more to reinforce the hold of the extended family than to undermine it, especially when the resources of all the family may be needed for that person's education.

To some, it appears that the "educated" African from a tribal background is the lucky member of the family. Some of the "educated" ones have said, however, that they were the unlucky ones. 24 On the one hand, they were educated out of the traditional society. On the other, they are aware of the great expense in terms of available resources, of their education to the family, and they realize that their education was viewed more as a family investment than a means to insure the "good life" for themselves. Thus, they are "condemned" to live a sort of schizoid existence in two sub-cultures. One permits them to forget the extended family. The other says they cannot. Tables 2 and 4 show the contradictory attitudes which the students hold in this respect. Almost two-thirds think their first obligation after marriage is to some member of the extended family other than their own wife (or wives), and children. Furthermore, over ninety percent think that the most important thing in life is to help one's family in time of need. (Under the present social and economic conditions in Sierra Leone, this is almost constantly.) Yet only slightly over one-half think that nothing in life is worth leaving one's family, and an equal proportion like to spend holidays at home with their parents. The seemingly big contradiction is that only five percent would stay near their families even if it means giving up a good job. This contradiction is more apparent than real, because for the most part the only available jobs are in Freetown. The country is so small that a day's ride by lorry or "mammy wagon" would make a son, brother or uncle available to anyone. One cannot, therefore, be away from his family as long as he remains in the country. It is alleged that the only way a Sierra Leonean can escape the physical hold of the extended family successfully is to leave the country and ignore his mail. Preferably he should go to another continent. If this is not possible, other parts of Africa will suffice, providing overland transportation is not possible. One can hypothesize, however, that very few, if any, escape the emotional grip of the extended family. Successful professionals who have lived abroad have related stories of how they were forced to return to Sierra Leone because relatives kept "coming to them" at night when they were asleep; they kept hearing a relative's voice telling them to come home; or the juju that they had long ceased to believe in suddenly became real again because a practitioner in Sierra Leone kept sending them signs. This is a promising research area, both methodologically and substantively, and its implications for the mental health movement in both developed and undeveloped countries cannot be ignored.

\section{Implications}

The data demonstrate that students in the schools studied have attitudes toward certain areas of family life which represent radical departures from the traditional society. It is not known whether or not the students are representative of all secondary school students in the country. If it is assumed that they are representative and that they will adopt the practices which their attitudes now favor, it is possible to state hypotheses with respect to future trends in family practices among the "educated" class in Sierra Leone. These are: (1) polygyny as a form of marriage will not be practiced by educated Sierra Leoneans except in cases where persons occupy status-roles which specify this form of marriage; (2) the role of parents in arranging marriages will shift from a contractual arrangement, wherein the parents exercise authority in choice of partner, making financial payments and supervising the love relationship between the mates, to one wherein parents act as preceptors for their sons to signify family solidarity and acceptance of the bride and her family; (3) romantic love and pre-marital courtship will become increasingly more important in marriage; (4) the size of the nuclear family will decrease; and (5) the extended family will continue its strong physical and emotional grip on family members until the role which the family now plays in mutual aid is shifted to some other agency. A state operated social security program and universal free education, together with a relatively high level of economic development, appear to be factors which must precede the weakening of the extended family's hold on its members.

It must be remembered that the students in secondary schools represent a minute proportion of the total population and a very small proportion of persons in their age group. In addition, the students come from families who have already made the transition from the traditional society to the more urbane Western outlook, or are in the process of doing so. For this reason it is most likely that the changes which were hypothesized for the "educated" class will not be adopted by a major proportion of the general population or of the current secondary school age group. There are factors other than education, however, which may contribute to change. It is likely, for example, that a higher level of economic activity will take a number of people out of subsistence 
agriculture. This will make polygyny and large families impractical if this shift is accompanied by a change in social values which specifies education for children and so on. Increasing contact with the larger society through the radio and with change agencies will likely have an impact on this generation of youth also. Hence, there is likely to be some erosion of traditional values even among this generation of primary school students who do not attend secondary school.

\section{FOOTNOTES}

1 T. J. Alldridge, Sherbro and Its Hinterland, London: MacMillan, 1901; T. J. Alldridge, A Transformed Colony, London: Seeley and Company, 1910; Kenneth Little, The Mende of Sierra Leone, London: Routledge and Kegan Paul, 1951; R. N. Finnegan, Survey of the Limba People of Northern Sierra Leone, London: Her Majesty's Stationery Office, 1965; Robert T. Parsons, Religion in an African Society, Leiden, Netherlands: E. J. Briel, 1964; J. I. Clarke, (Ed.), Sierra Leone in Maps, London: University of London Press, Ltd., 1966. A summary of the ethnographic materials on the Temne, Koranko, Susu, and Mandingo is presented in M. McCulloch, People of the Sierra Leone Protectorate, London: International Ethnographic Survey, West Africa, II, 1950.

2 The British government established Freetown in 1788 as a colony for freed slaves. It grew to an area of approximately 256 square miles and attained the status of a Crown Colony in 1808. In 1896, the British government drew the boundaries for the interior and declared it a protectorate. Each had its own government until 1924 when the two were brought together under a common legislature. The population of the Protectorate considered itself African and the population of the Colony considered itself British. Even today, many Creoles refer to England as home. The country is currently divided into 13 administrative districts, one of which is the former colony. The former protectorate is divided into 146 Chiefdoms and each is ruled by a Paramount Chief. See Christopher Fyfe, $A$ History of Sierra Leone, London: Oxford University Press, 1964. Two recent books of particular interest to sociologists are: Micheal P. Banton, West African City: A Study of Tribal Life in Freetown London: Oxford University Press, 1966; and Arthur R. Porter, Creoledom: A Study of the Development of Freetown Society, Cambridge: The University Press, 1965.

3 The secret societies remain an important part of the traditional societies in transition, and every non-Creole male and female must undergo initiation in order to be considered an adult. Several college students have related stories to me of how they refused to go for initiation into Poro but were subsequently kidnapped and taken into the sacred bush. One student has described in detail his initiation into the Poro society in Konoland. Since Poro ranks second in the hierarchy of societies among the Kono, the ceremony of initiation may last as long as six months. If the initiate has not been circumcised, this rite is performed. The initiated are then taught to dance and to survive under adverse conditions. Later they must undergo series of incisions from the nape of the neck to just above the buttock. If a boy does not scream and have to be "backed" or held, he will receive three rows of incisions on the back and one on each side from the arm pits to the hip. My informant says that boys who receive the five rows of scars can "get any woman they want" when they show their naked back.

4 Raymond F. Hopkins, "Christianity and Socio-Political Change in Sub-Saharan Africa", Social Forces: Vol. 44, (1966), pp. 555-562.

5 Gerald O. Windham, "Educational Development in Sierra Leone", unpublished manuscript, Njala University College, 1967.

6 Juju is a sort of magic in which a fetish is used to ward off evil spirits, cure incurable ailments, insure a good harvest of rice and so on. There are juju men in the traditional societies who can fix anything for a price. In the society in transition, the injection of the white doctor is believed to be more powerful than the juju man's medicine. The most powerful injections are those given with a dull needle. If it does not hurt, it is no good. Interview with Sister Hilary Lyon, M. D., Serabu Mission, 1967.

7 This argument is supported by Professor Osmond's Analysis of Preferred Type of Marriage in 500 Societies. See: Marie W. Osmond, "Toward Monogamy: A Cross-Cultural Study of Correlates of Type of Marriage", Social Forces: Vol. 44, (1965), pp. 8-16.

8 W. L. G. Muir, "Industrial Training in Sierra Leone", Edinburgh: The University of Edinburgh, 1965 (mimeo).

9 T. Peter Imari, "Role Expectation in the Courtship Situation in Ghana", Social Forces: Vol. 42, (1963), pp. 147-156.

10 Other research in West Africa on family relationships shows a similar pattern. See: Kenneth Little "Attitudes Toward Marriage and the Family Among Young Educated Sierra Leoneans", in P. E. Lloyd, (Ed.), The New Elites of Tropical A frica, London' Oxford University Press, 1966, pp. 139-160.

11 This study is related to the Southern Regional Project on Occupational and Educational Aspirations of High School Students being conducted by Departments of Rural Sociology in several Southeastern States. 
12 The General Certificate of Education. This examination is given upon completion of Form $\mathrm{V}$ in secondary school. Five passes are required for admission to a university college.

13 D. L. Sumner, Education in Sierra Leone, Freetown: The Government of Sierra Leone, 1963, pp. 139-140. This book presents an excellent analysis of the current status of the education system in Sierra Leone. It shows the role of the Government and Christian missions in shaping the character of education as well as the relative contribution of each in terms of resources.

14 Milton Harvey, "Sierra Leone's Largest Provincial Town", Sierra Leone Studies, New Series No. 18, (1966), pp.29-42.

15 Students who do vocational courses in secondary school are at a disadvantage when they sit the G.C.E. examination because this examination covers academic subject fields only. It is highly unlikely that any system of vocational education will become operative in the country until the G.C.E. makes provisions for operative in the country until the G.C.E. makes provisions for
these subjects. Interview with F. S. Anthony, Principal, Taiama Seceondary School, 1967.

16 There are 15 indigenous tribes. The Mende and Temne make up 31 and 30 percent of the total population respectively, 1963 Census of Population, Vol. 1, Freetown: Central Statistics Office, 1965.

17 Sumner, op. cit., p. 231.

18 Secondary schools require expensive fees, uniforms, books and other supplies. In addition, room and board must be paid if the student cannot live at home, stay with a relative or become a ward of someone who lives in the community. For a discussion of the system whereby boys become adoptees of persons in return for room and board while attending school, see: H. Lynch-Shyllon, "The Effect of the Ward System on School in the Colony of Sierra Leone", unpublished Dip. Ed. Thesis, The University of Durham, 1956. See also: Robert Wellesley Cole, Kossoh Town Boy, Cambridge: The Cambridge University Press, 1960.

19 Sixty-five percent of the total population lives in farm households. The average farm size is 3.9 acres. Only five crops were sold by more than 10 percent of farmers in 1965 and 98 percent of all farmers used only human power. Agricultural Statistical Survey of Sierra Leone, 1965-1966, Freetown: Central Statistics Office, Sierra

20 At the Chiefdom level a person can take another person to the Chief's court for an insult, practicing witchcraft, and so on. If damage is awarded it goes to the plaintiff and not to the native administration coffers. If a person can prove that his wife has had relations with another man he can force his wife's lover to pay him damage. It is alleged that many women contrive with thei husbands to get naive men in the wife damage trap. See: Roy Lewis, Sierra Leone, A Modern Portrait, London: Her Majesty's Stationery Office, 1954, pp. 138.

21 Ruth Shonle Cavan, The American Family, New York: Thomas Y. Crowell Company, 1955, pp. 345-350

22 Lewis, op. cit.,pp. 220.

23 This point was discussed in a conference on nutrition held at Njala University College in 1967. Representatives from the helping professions of social work, medicine, child welfare and other government and voluntary change agencies agreed that one of the major needs in Sierra Leone today is laws to regulate adoption and to protect the welfare of children.

24 I have discussed the hold of the extended family on its members with many educated Africans from Sierra Leone and other West African countries. It is unlikely that most of them would exchange places with their uneducated brothers. However, all of them seem to experience much conflict regarding their obligations to the extended family. They want to see the system changed but are resigned to live their lives in this intolerable situation. Many say, however, that their children will not have to experience this conflict, and that the system will weaken in specific families with each new generation of the "educated". 